\title{
Chapter 13 \\ Influence of B Vitamins on Proliferation and Differentiation of Osteoblastic Bovine Cell Cultures: An In Vitro Study
}

\author{
Kent Urban, Julia Auer, Sebastian Bürklein, and Ulrich Plate
}

\begin{abstract}
Minerals and vitamins affect bone formation, genetics, nutrition, and hormones. Studies mainly focus on the elucidation of the metabolic pathways during biomineralization to get an idea of how to promote the process of biomineralization in vivo and in vitro. One qualified approach to reach this is to investigate the influence of different substances on the proliferation and differentiation of osteoblastic cell cultures in vitro. The aim of this study was to investigate the effects of different types of single $\mathrm{B}$ vitamins $\left(\mathrm{B}_{6}, \mathrm{~B}_{9}\right.$, and $\left.\mathrm{B}_{12}\right)$ and a vitamin $\mathrm{B}$ complex $\left(\mathrm{B}_{1}\right.$, $\mathrm{B}_{2}, \mathrm{~B}_{3}, \mathrm{~B}_{5}, \mathrm{~B}_{6}, \mathrm{~B}_{9}$, and $\mathrm{B}_{12}$ ) on proliferation and differentiation of primary bovine osteoblastic cells in vitro. The proliferation of osteoblastic cells during the experiments was evaluated by cell number analysis while cultivating. The expression of marking proteins of the osteogenic differentiation was evaluated by immunohistochemistry. Previous experiments with seven different B vitamins in different concentrations revealed a positive effect on cell proliferation with increasing concentration caused by three $B$ vitamins: pyridoxal $\left(\mathrm{B}_{6}\right)$, folic acid $\left(\mathrm{B}_{9}\right)$, and cobalamine $\left(\mathrm{B}_{12}\right)$. The use of vitamin $\mathrm{B}_{6}, \mathrm{~B}_{9}$, and $\mathrm{B}_{12}$ in different concentrations resulted in a significant increase of cell proliferation $(p<0.05)$. But neither the $\mathrm{B}$ vitamins nor the B vitamin complexes stimulated the expression of the typical bone cell proteins.
\end{abstract}

Keywords Vitamins · Vitamin B · Bone formation · Bone regeneration · Bone metabolism . In vitro biomineralization

\footnotetext{
K. Urban

Department of Periodontology and Operative Dentistry in the School of Dentistry,

University of Münster, Münster, Germany

e-mail: Kent.Urban@ukmuenster.de

J. Auer · U. Plate $(\bowtie)$

Department of Maxillofacial Surgery, VABOS, University of Münster, Münster, Germany e-mail: plateu@uni-muenster.de
}

\section{S. Bürklein}

Central Interdisciplinary Ambulance in the School of Dentistry, University of Münster,

Münster, Germany

e-mail: Sebastian.Buerklein@ukmuenster.de 


\subsection{Introduction}

Focussing on the rapid development of implant- and bone-substitute materials as well as their integration in autologous tissue and optimized wound healing processes, it gets more and more important to give well-known therapies new perspectives. For a better adaption of implants in surrounding tissue, not only material's biocompatibility but also bone regeneration as a part of wound healing becomes subject of scientific research. Many existing therapies on bone regeneration dealing with vitamin D and calcium supplementation are well established (Avenell et al. 2014; Javed et al. 2016; Vandenbroucke et al. 2017). The effect of some other single vitamins or vitamin complexes is already investigated (Masse et al. 2010; Elste et al. 2017). Nevertheless, the effects in direct supplementation with vitamins in bone defects on bone regeneration are not completely understood yet (Owen et al. 1990; Herrmann et al. 2013).

\subsection{Materials and Methods}

For the experiments, two different cell culture mediums were used:

(a) Medium MP (High Growth Enhancement Medium without L-glutamine, MP Biomedicals GmbH, Eschwege, Germany) and

(b) Medium PAN (High Growth Enhancement Medium without L-glutamine and without B vitamins; PAN Bio-Tek, Bad Frierdrichshall, Germany).

Both mediums were supplemented with 4\% FCS (fetal calf serum) (Biochrom, Berlin, Germany), $10.000 \mathrm{IU} / \mathrm{ml}$ penicillin, $10.000 \mu \mathrm{g} / \mathrm{ml}$ streptomycin, $250 \mu \mathrm{g} / \mathrm{ml}$ amphotericin B, and $200 \mathrm{mM}$ L-glutamine (Biochrom KG Seromed, Berlin, Germany). Primary bovine osteoblast-like cells were used in this study. The cells were derived from the periosteum of calf metacarpus according to the instructions of Jones and Boyde (1977). Tissue explants were cultured for 4 weeks in medium MP supplemented with $10 \%$ FCS, $10.000 \mathrm{IU} / \mathrm{ml}$ penicillin, $10.000 \mu \mathrm{g} / \mathrm{ml}$ streptomycin, $250 \mu \mathrm{g} / \mathrm{ml}$ amphotericin $\mathrm{B}, \quad 10 \mathrm{mM}$ ß-glycerophosphate, and $200 \mathrm{mM}$ L-glutamine (Biochrom KG Seromed, Berlin, Germany), at $37^{\circ} \mathrm{C}$ and $5 \%$ $\mathrm{CO}_{2}$ in humidified air. The medium was replaced once a week. When cells reached confluence, they were harvested $\left(20 \mathrm{~min}\right.$ incubation at $37^{\circ} \mathrm{C}$ with $0.4 \mathrm{~g}$ collagenase, 98.8 mg nutrient mixture (HAM's F - 10) in 10 ml HEPES (2-[4-(2-hydroxyethyl)1-piperazinyl] ethane sulfonic acid), repeatedly washed with phosphate-buffered saline (PBS), subsequently incubated for $15 \mathrm{~min}$, and centrifuged. Pellets were resuspended in PBS and the cell number was determined in a cell counter (CASYWI Modell TT, Schärfe System, Reutlingen, Germany). Osteoblasts $\left(10.000 / \mathrm{cm}^{2}\right)$ were seeded on 24-well plate plastic petri dishes (Nunc TFS, Roskilde, Denmark) with different mediums and B vitamin concentrations. Cell proliferation was determined after 1, 3, and 5 days, respectively. Cell morphology evaluation was performed by 
means of light microscopy. To determine the cell number, digital photos were taken under standardized conditions and cells were counted using the software program ImageJ with the plug-in Cell Counter. The experiments were repeated six times and all data were analyzed using one-way analysis of variance and post hoc Scheffé Test. As basic level of vitamin complex, the standard concentration of included B vitamins in medium MP was used (4 mg/l thiamine, $0,4 \mathrm{mg} / \mathrm{l}$ riboflavin, $4 \mathrm{mg} / \mathrm{l}$ niacin, $4 \mathrm{mg} / \mathrm{l}$ pantothenic acid, $4 \mathrm{mg} / \mathrm{l}$ pyridoxal, and $4 \mathrm{mg} / \mathrm{l}$ folic acid). This concentration was called medium $\mathrm{MP}_{0}$ and served as negative control for each group. Vitamin concentration was increased to achieve different concentrations (from basic level up to fourfold concentration) and called $\mathrm{MP}_{1}-\mathrm{MP}_{3}$ (Table 13.1). Vitamin $\mathrm{B}_{12}$ was not included and only solely added to medium MP. Based on medium PAN without B vitamins, single B vitamins were also added in different concentrations (from 4 to $12 \mu \mathrm{g} / \mathrm{ml}$ ) (Table 13.1). Medium PAN without any B vitamins was called $\mathrm{PAN}_{0}$ and was used as negative control for all experiments with medium PAN. An increase in cell number after 3 and 5 days was observed in all test groups (Figs. 13.1 and 13.2). For cell differentiation, collagen I, osteonectin, and osteocalcin were assessed by immunohistochemistry (Dako EnVision System, Dako, Hamburg, Germany) under standardized conditions with fluorescence microscopy

Table 13.1 Different B-vitamin concentrations in $\mu \mathrm{g} / \mathrm{ml}$ for (a) medium $\mathrm{MP}, \mathrm{MP}_{0}=$ standard $\mathrm{B}$ vitamin concentration (negative control), $\mathrm{MP}_{1}=$ double concentration of vitamin, $\mathrm{MP}_{2}=$ triple concentration of vitamin, $\mathrm{MP}_{3}=$ fourfold concentration of vitamin and (b) medium PAN, PAN $\mathrm{N}_{0}=$ without vitamin (negative control), $\mathrm{PAN}_{1}=4 \mu \mathrm{g} / \mathrm{ml}, \mathrm{PAN}_{2}=8 \mu \mathrm{g} / \mathrm{ml}$, and $\mathrm{PAN}_{3}=12 \mu \mathrm{g} / \mathrm{ml}$ vitamin

\begin{tabular}{l|l|l|l|l|l|l|l}
\hline Medium/vitamin & B1 & B2 & B3 & B5 & B6 & B9 & B12 \\
\hline $\mathrm{MP}_{0}$ & 4 & 0,4 & 4 & 4 & 4 & 4 & 0 \\
\hline $\mathrm{PAN}_{0}$ & 0 & 0 & 0 & 0 & 0 & 0 & 0 \\
\hline $\mathrm{MP}_{1}$ B6 & 4 & 0,4 & 4 & 4 & 8 & 4 & 0 \\
\hline $\mathrm{MP}_{2}$ B6 & 4 & 0,4 & 4 & 4 & 12 & 4 & 0 \\
\hline $\mathrm{MP}_{3}$ B6 & 4 & 0,4 & 4 & 4 & 16 & 4 & 0 \\
\hline $\mathrm{MP}_{1}$ B9 & 4 & 0,4 & 4 & 4 & 4 & 8 & 0 \\
\hline $\mathrm{MP}_{2}$ B9 & 4 & 0,4 & 4 & 4 & 4 & 12 & 0 \\
\hline $\mathrm{MP}_{3}$ B9 & 4 & 0,4 & 4 & 4 & 4 & 16 & 0 \\
\hline $\mathrm{MP}_{1}$ B12 & 4 & 0,4 & 4 & 4 & 4 & 4 & 8 \\
\hline $\mathrm{MP}_{2}$ B12 & 4 & 0,4 & 4 & 4 & 4 & 4 & 12 \\
\hline $\mathrm{MP}_{3}$ B12 & 4 & 0,4 & 4 & 4 & 4 & 4 & 16 \\
\hline $\mathrm{PAN}_{1}$ B6 & 0 & 0 & 0 & 0 & 4 & 0 & 0 \\
\hline $\mathrm{PAN}_{2}$ B6 & 0 & 0 & 0 & 0 & 8 & 0 & 0 \\
\hline $\mathrm{PAN}_{3}$ B6 & 0 & 0 & 0 & 0 & 12 & 0 & 0 \\
\hline $\mathrm{PAN}_{1}$ B9 & 0 & 0 & 0 & 0 & 0 & 4 & 0 \\
\hline $\mathrm{PAN}_{2}$ B9 & 0 & 0 & 0 & 0 & 0 & 8 & 0 \\
\hline $\mathrm{PAN}_{3}$ B9 & 0 & 0 & 0 & 0 & 0 & 12 & 0 \\
\hline PAN $_{1}$ B12 & 0 & 0 & 0 & 0 & 0 & 0 & 4 \\
\hline PAN $_{2}$ B12 & 0 & 0 & 0 & 0 & 0 & 0 & 8 \\
\hline PAN $_{3}$ B12 & 0 & 0 & 0 & 0 & 0 & 0 & 12 \\
\hline
\end{tabular}




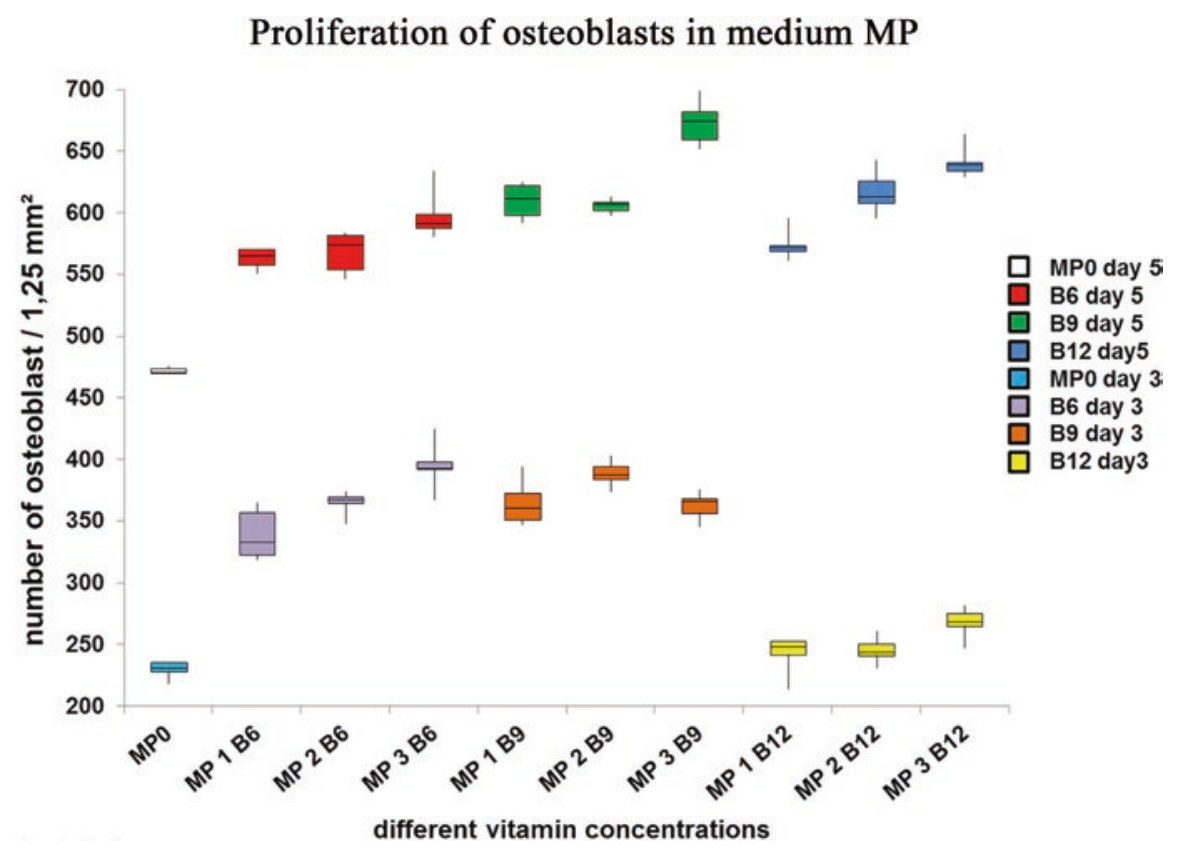

Fig. 13.1 Cell proliferation with B vitamin complex and single B vitamins in medium MP. Medium MP with B vitamin complex was used with different single vitamin B concentrations over 5 days. All groups started with nearly the same cell number at day $1 p<0.05$ (data not shown). An increase in cell number after 3 and 5 days was observed in all groups

(Axioplan 2, Carl Zeiss, Germany) and processed using AxioVision 3.1 software (Carl Zeiss, Germany).

Sixty thousand osteoblasts $/ \mathrm{cm}^{2}$ were seeded in $100 \times 20 \mathrm{~mm}$ plastic petri dishes (TPP, Trasadingen, Schweiz). After cultivation for 14 days at $37{ }^{\circ} \mathrm{C}$ in an atmosphere of $5 \% \mathrm{CO}_{2}$ in the different media, osteoblastic cells were fixed with methanol and primary antibodies were used (diluted 1:100 with Blocking Solution): anticollagen I (Biotrend, Cologne, Germany), anti-osteocalcin (TaKaRa Bio, MoBiTec, Goettingen, Germany), and anti-osteonectin (TaKaRa Bio, MoBiTec, Goettingen, Germany). Digital images were taken under standardized conditions by fluorescence microscopy (Axioplan 2 Carl Zeiss, Germany) and processed using the software AxioVision 3.1 (Carl Zeiss, Germany).

\subsection{Results and Discussion}

Proliferation of osteoblastic cells during the experiments was evaluated by cell number analysis during culture. Expression of marking proteins of osteogenic differentiation was assessed by immunohistochemistry. Proliferation and 


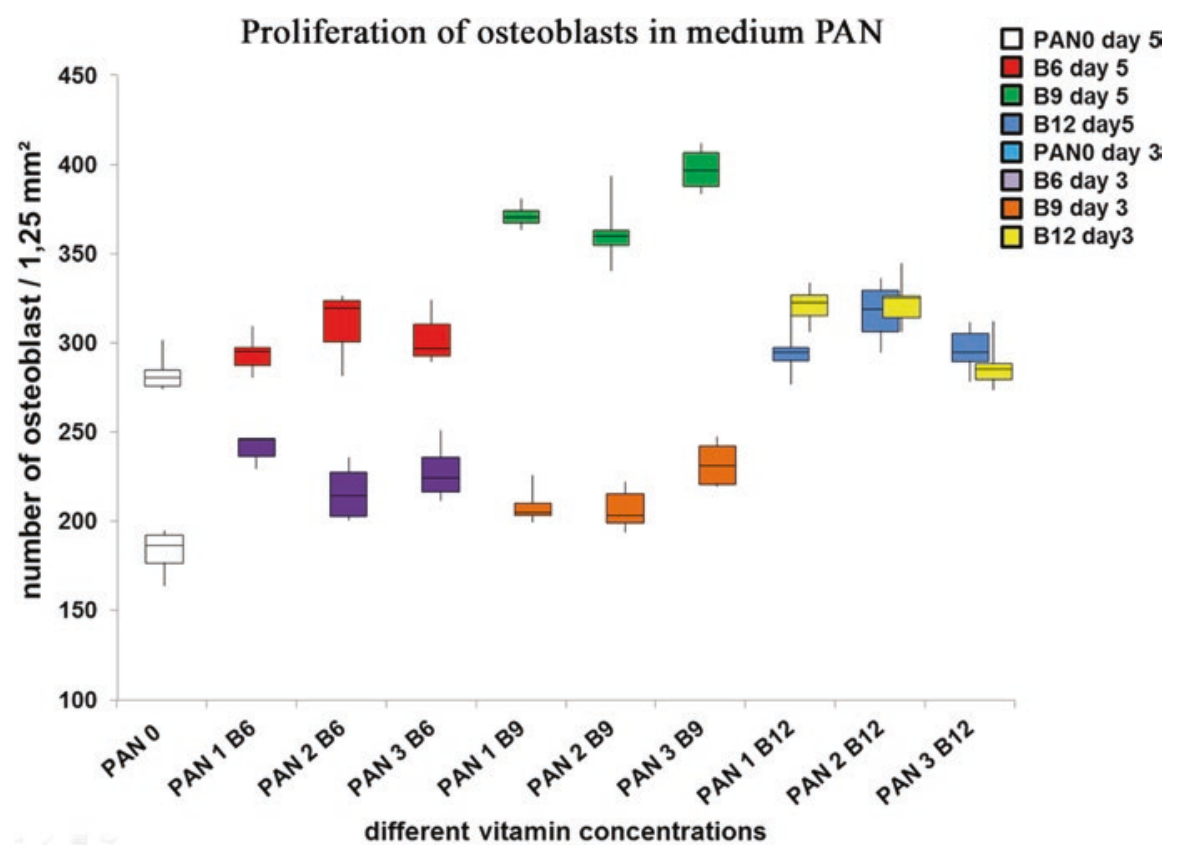

Fig. 13.2 Cell proliferations with single B vitamins in medium PAN. Medium PAN was used only with different single vitamin B concentrations over 3 and 5 days. All groups started with nearly the same cell number at day $1 p<0.05$ (data not shown). An increase in cell number after 3 and 5 days was observed in all groups

differentiation of osteoblasts enable the production of extracellular matrix (ECM) and is therefore the initial step in the formation of calcified tissue, especially bone.

This study mainly focuses on the elucidation of the metabolic pathways during biomineralization to get an idea of these processes in vivo and in vitro. Previous experiments with seven different $\mathrm{B}$ vitamins in different concentrations revealed a positive effect on cell proliferation with increasing concentrations caused by three $\mathrm{B}$ vitamins pyridoxal $\left(\mathrm{B}_{6}\right)$, folic acid $\left(\mathrm{B}_{9}\right)$, and cobalamine $\left(\mathrm{B}_{12}\right)$ (Dhonukshe-Rutten et al. 2003; Swart et al. 2016).

Characteristics of the B vitamins are:

- Essential nutrients that must be added to the body for normal cell formation, growth, and development

- Catalyzing and regulatory functions as cofactors and enzymes

- Being water-soluble, without danger of hypervitaminosis when overdosed

Under the conditions of the present study, the use of vitamin $\mathrm{B}_{6}, \mathrm{~B}_{9}$, and $\mathrm{B}_{12}$ in different concentrations resulted in a significant increase of cell proliferation $(p<0.05)$. The negative control groups $\mathrm{MP}_{0}$ and $\mathrm{PAN}_{0}$ differed significantly from all other groups $\mathrm{MP}_{1,2,3}$ and $\operatorname{PAN}_{1,2,3}(\mathrm{p}<0,05)$ (Table 13.1, Figs. 13.1, 13.2, and 13.3). 

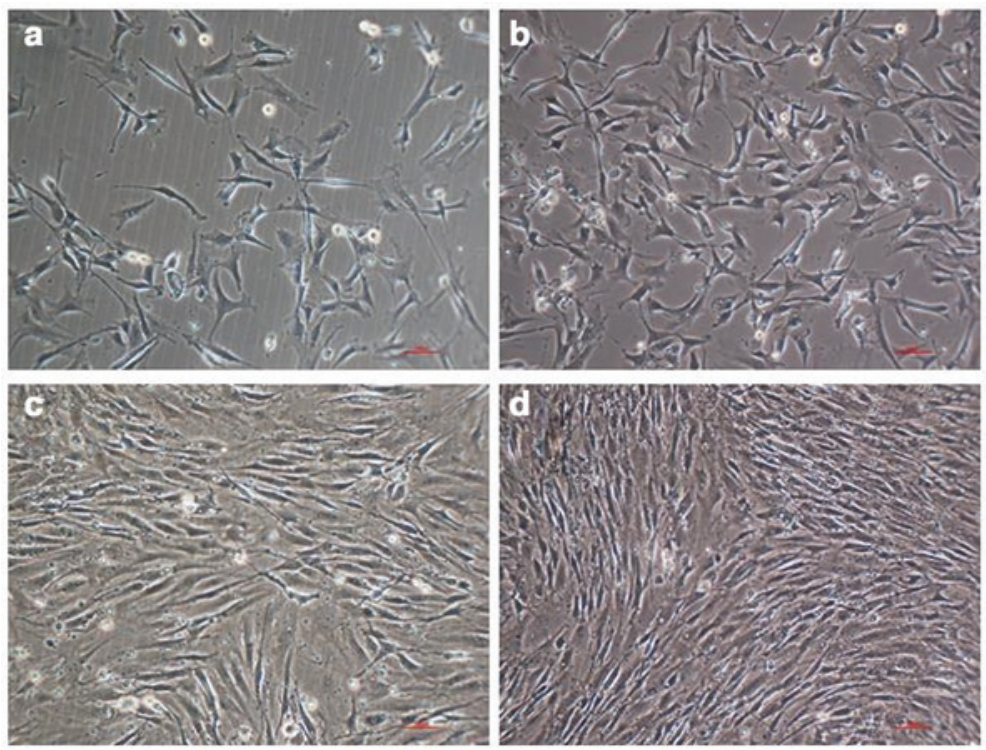

Fig. 13.3 Osteoblastic cells (a) after 3 days of incubation medium $\mathrm{PAN}_{0}$; (b) after 3 days of incubation medium $\mathrm{PAN}_{3}$ (with vitamin $\mathrm{B}_{9}$ ); (c) after 5 days of incubation medium $\mathrm{PAN}_{0}$, (d) after 5 days of incubation medium $\mathrm{PAN}_{3}$ (with vitamin $\mathrm{B}_{9}$ )

Finally, supplementation of certain vitamins in an appropriate concentration significantly increased proliferation and improved growth of osteoblast-like cells. Probably, this increased cell growth leads to a superior wound healing and bone regeneration.

Using vitamin culture media to enhance proliferation and collagen formation (Herrmann et al. 2007) of osteoblast-like cells during culturing seems to be quite reasonable.

During different stages of differentiation, several proteins are synthesized by the osteoblasts (Roach 1994; Kim et al. 1996):

(a) Collagen type I, the main component of the ECM

(b) Non-collagenous proteins like alkaline phosphatase

(c) Osteonectin

(d) Later in the differentiation progress osteocalcin

While collagen type I as well as the protein marker osteonectin could be detected by immunohistochemistry at the end of the experiments (Fig. 13.4), none of the cell cultures showed any signs of osteocalcin expression. Neither the B vitamins nor the B vitamin complexes significantly stimulated the expression of the typical bone cell proteins.

Supplementation of other vitamins, e.g., ascorbic acid, supports the synthesis of collagen, and the ECM (extracellular matrix) (Urban et al. 2012) seemed to have a positive effect compared to vitamin-free cultures (Najeeb et al. 2016; Fratoni and Brandi 2015; Zhaoli Dai and Koh 2015). Bioactive vitamins placed on implant sur- 


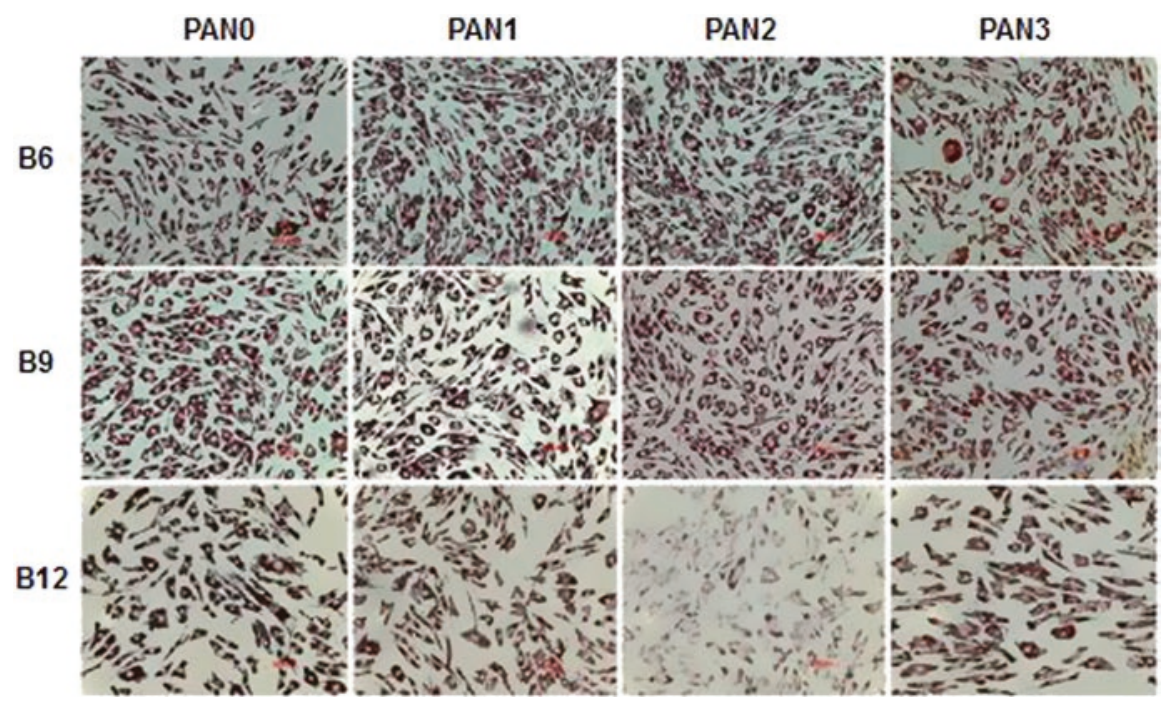

Fig. 13.4 Immunohistochemical analyses of collagen (primary antibody "anti-collagen I (Biotrend, Cologne, Germany)") in medium PAN with single vitamins $\mathrm{B}_{6}, \mathrm{~B}_{9}$, and $\mathrm{B}_{12}$

face may positively affect wound healing due to direct transmission into surrounding tissue. Mixing those vitamins into bone-substitute materials could be another beneficial aspect in bone regeneration by diffusion into the wound (Bartold et al. 2016). Further investigations should follow with the aim to increase supportive effects of vitamins on biological processes such as wound healing, bone regeneration, and revised healing of bone implants.

Acknowledgment Financial support of the Arbeitsgemeinschaft für Elektronenoptik e.V., Germany, is gratefully acknowledged.

\section{References}

Avenell A, Mak JCS, O'Connell D (2014) Vitamin D and vitamin D analogues for preventing fractures in post-menopausal women and older men. Cochrane Database Syst Rev (4) Art. No.: CD000227

Bartold PM, Gronthos S, Ivanovski S, Fisher A, Hutmacher DW (2016) Tissue engineered periodontal products. J Periodontal Res 51:1-15

Dhonukshe-Rutten RA, Lips P, de Jong N, Chin A, Paw MJM, Hiddink GJ, van Dusseldorp M, de Groot LC, van Staveren WA et al (2003) Vitamin $B_{12}$ status is associated with bone mineral content and bone mineral density in frail elderly women but not in men. J Nutr 133(3):801-807

Elste V, Troesch B, Eggersdorfer M, Weber P (2017) Emerging evidence on neutrophil motility supporting its usefulness to define vitamin $C$ intake requirements. Nutrients 9(5):503

Fratoni V, Brandi ML (2015) B vitamins, homocysteine and bone health. Nutrients 7:2176-2192

Herrmann M, Umanskaya N, Traber L, Schmidt-Gayk H, Menke W, Lanzer G, Lenhart M, Schmidt JP, Herrmann W (2007) The effect of B-vitamins on biochemical bone turnover Osteocalcin und Kollagen Typ I markers and bone mineral density in osteoporotic patients: a 1-year double blind placebo controlled trial. Clin Chem Lab Med 45(12):1785-1792 
Herrmann W, Kirsch SH, Kruse V, Eckert R, Gräber S, Geisel J, Obeid R (2013) One year B and D vitamins supplementation improves metabolic bone markers. Clin Chem Lab Med 51(3):639-647

Javed F, Malmstrom H, Kellesarian SV, Al-Kheraif AA, Vohra F, Romanos GE (2016) Efficacy of vitamin D3 supplementation on osseointegration of implants. Implant Dent 25(2):281-287

Jones SJ, Boyde A (1977) The migration of osteoblasts. Cell Tissue Res 184:179-193

Kim GS, Kim CH, Park JY, Lee KU, Park CS (1996) Effects of vitamin $B_{12}$ on cell proliferation and cellular alkaline phosphatase activity in human bone marrow stromal osteoprogenitor cells and UMRI06 osteoblastic cells. Metabolism 45:1443-1446

Masse PG, Jougleux JL, Tranchant CC, Dosy J, Caissie M, Coburn SP (2010) Enhancement of calcium/vitamin D supplement efficacy by administering concomitantly three nutrients essential to bone collagen matrix for the treatment of osteopenia in mid-dle-aged women: a one-year follow-up. J Clin Biochem Nutr 46(1):20-29

Najeeb S, Zafar MS, Khurshid Z, Zohaib S, Almas K (2016) The role of nutrition in perio-dontal health: an update. Nutrients 8:530

Owen TA, Aronow M, Shalhoub V, Barone LM, Wilming L, Tassinari MS, Kennedy MB, Pockwinse S, Lian JB, Stein GS (1990) Progressive development of the rat osteoblast phenotype in vitro: reciprocal relationships in expression of genes associated with osteoblast proliferation and differentiation during formation of the bone extracellular matrix. J Cell Physiol 143:420-430

Roach HI (1994) Why does bone matrix contain non-collagenous proteins? The possible roles of osteocalcin, osteonectin, osteopontin and bone sialoprotein in bone mineralisation and resorption. Cell Biol Int 18:617-628

Swart KM, Ham AC, van Wijngaarden JP, Enneman AW, van Dijk SC, Sohl E, Brouwer-Brolsma EM, van der Zwaluw NL, Zillikens MC, Dhonukshe-Rutten RA, van der Velde N, Brug J, Uitterlinden AG, de Groot LC, Lips P, van Schoor NM (2016) A randomized controlled trial to examine the effect of 2-year vitamin $B_{12}$ and folic acid supplementation on physical performance, strength, and falling: additional findings from the B-PROOF study. Calcif Tissue Int 98(1):18-27

Urban K, Höhling HJ, Lüttenberg B, Szuwart T, Plate U (2012) An in vitro study of osteo-blast vitality influenced by the vitamins $\mathrm{C}$ and E. Head Face Med 8(25)

Vandenbroucke A, Luyten F, Flamaing J, Gielen E (2017) Pharmacological treatment of osteoporosis in the oldest old. Clin Interv Aging 12:1065-1077

Zhaoli Dai Z, Koh WP (2015) Review B-vitamins and bone health-a review of the current evidence. Nutrients 7:3322-3346

Open Access This chapter is licensed under the terms of the Creative Commons Attribution 4.0 International License (http://creativecommons.org/licenses/by/4.0/), which permits use, sharing, adaptation, distribution and reproduction in any medium or format, as long as you give appropriate credit to the original author(s) and the source, provide a link to the Creative Commons license and indicate if changes were made.

The images or other third party material in this chapter are included in the chapter's Creative Commons license, unless indicated otherwise in a credit line to the material. If material is not included in the chapter's Creative Commons license and your intended use is not permitted by statutory regulation or exceeds the permitted use, you will need to obtain permission directly from the copyright holder.

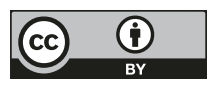

